Psychother Psychosom 1991;56:114-115

\title{
Sonnet for a Grecian
}

Heed not that ancient bard who snidely wrote, 'I fear the Greeks e’en bearing gifts,' belied The truth, and tuneless piped a sour note, Misled by envy and by petty Latin pride. 'Tis time to tell it straight in candid meter. I know a Greek who precious cargo bore (Sing, O Muse, of Siphnos' scion, Peter!) From storied Lesbos to our westward shore -Gifts of wit and wisdom and creative fire, A cellar full of Samian wine and cheer, A quiet warmth, vast pedagogic skills, a choir Of therapeutic talents without peer -

Rash is the bumbling fool who'd try to tell us We are not blest with cherished gifts from Hellas! J.C.N.

Sonnet for a Grecian

1. 115 